\title{
Belphégor
}

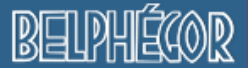

Littérature populaire et culture médiatique

13-1 | 2015

Distinctions That Matter/Fictions Économiques

\section{Jeanette Sloniowski and Marilyn Rose (eds), Detecting Canada : Essays on Canadian Crime Fiction, Televison, and Film}

\section{Rohan Maitzen}

\section{(2) OpenEdition}

\section{Journals}

Electronic version

URL: http://journals.openedition.org/belphegor/560

DOI: $10.4000 /$ belphegor.560

ISSN: 1499-7185

Publisher

LPCM

\section{Electronic reference}

Rohan Maitzen, « Jeanette Sloniowski and Marilyn Rose (eds), Detecting Canada : Essays on Canadian Crime Fiction, Televison, and Film », Belphégor [Online], 13-1 | 2015, Online since 09 May 2015,

connection on 22 September 2020. URL : http://journals.openedition.org/belphegor/560 ; DOI : https://doi.org/10.4000/belphegor.560

This text was automatically generated on 22 September 2020.

\section{(c) (i) (9)}

Belphégor est mis à disposition selon les termes de la Licence Creative Commons Attribution - Pas d'Utilisation Commerciale - Pas de Modification 4.0 International. 


\section{Jeanette Sloniowski and Marilyn Rose (eds), Detecting Canada: Essays on Canadian Crime Fiction, Televison, and Film}

Rohan Maitzen

\section{REFERENCES}

Jeanette Sloniowski and Marilyn Rose (eds), Detecting Canada : Essays on Canadian Crime Fiction, Televison, and Film, Wilfrid Laurier University Press, 2014, ISBN :

978-1-55458-926-5 
1 The title of Jeannette Sloniowski and Marilyn Rose's Detecting Canada is a clever (and presumably intentional) pun : all of the essays in this collection about Canadian crime fiction are also, either implicitly or explicitly, about how we can detect who or what is Canadian. Is it enough, for instance, for an author to have been born in Canada, or to be a Canadian citizen? What if a writer resides in Canada but sets his books elsewhere? Or, having moved away, returns to Canada only through her fiction? Or is being Canadian perhaps as much, or more, a matter of themes or motifs, wherever they play out - and if so, which ones? (Nobody will be surprised, I'm sure, to learn that likely contenders include "universal health care... Aboriginal

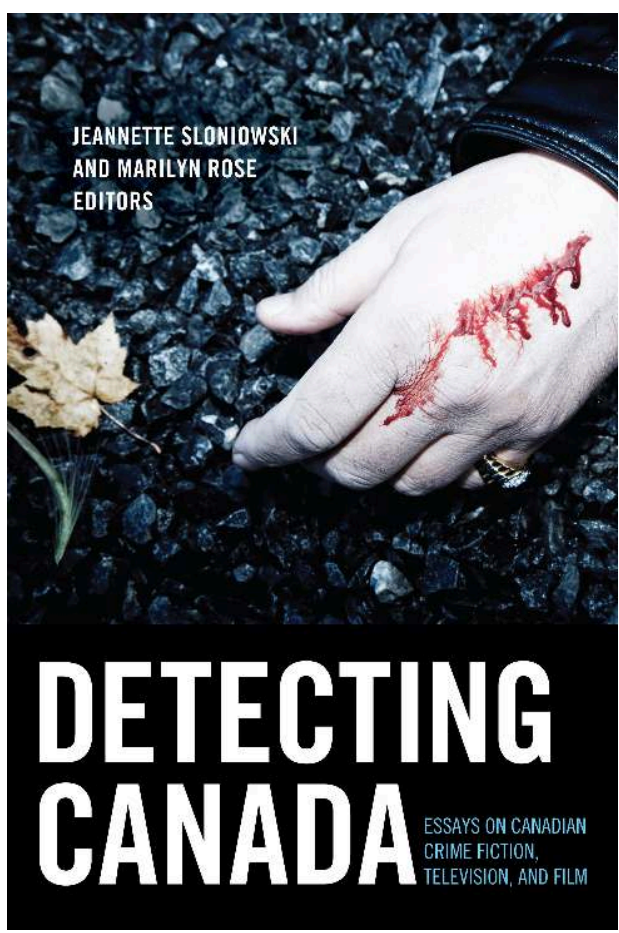
issues...immigration and multiculturalism...[and] hockey.")

2 Such questions inevitably dog decisions about who and what to cover in a book intended to fill a gap in studies of crime fiction, where the significant contributions of Canadian writers often go unnoticed. Though the editors are emphatic that they "do not claim to set out the parameters of a distinctive "Canadian School' of crime writing," nonetheless there are "commonalities" ; Canadian crime fiction, as "part of Canadian mass culture," reflects "certain overarching aspects of a Canadian national imaginary that reinforce national themes and stereotypes." Sustained attention to these issues, and to the writers and texts who make up the history and canon of Canadian crime fiction, is a reasonable, even a necessary, intervention into a critical discussion in which Canada is otherwise marginal.

3 But that sensible project stumbles over the persistent problem of defining "Canadian," which even just as a descriptive label proves tricky to apply. Peter Robinson, for instance, certainly one of the most recognizable names in Canadian crime fiction, lives in Toronto but hails from - and sets his novels in - Yorkshire. Thomas King is "an American-born Canadian citizen of Cherokee descent" ; he sets his novels in the United States (but, we're assured, "Canada is never far from his thoughts"). How Canadian are fictional detectives who are "clones of our American cousins... in adventures that could as easily take place in Des Moines or Dubuque as Moncton or Saskatoon"?

4 These are potentially valuable questions, as they provoke reflection on how as well as why we define ourselves by place. But it's one thing to explore the complexities of personal and cultural identity in an increasingly diasporic and globalized world. It's another when inquiry becomes regulation, as if being what one contributor explicitly calls "truly Canadian" means conforming to specific rules. "In the end," the editors observe in their introduction, "the 'problem' of foreign-born immigrant writers seems something of a non-issue, since their works, even when set elsewhere, can be seen to incorporate Canadian experience" - or, alternatively, couldn't it be a non-issue because 
writers aren't obliged to perform Canadianness in order to belong? "John Brady and Peter Robinson . . . may be excused" for "eschewing their homeland for foreign strands," says David Skene-Melvin

as they are immigrants to Canada who set their work in the past life that they know, but no such excuse forgives Janette Turner Hospital (writing as 'Alex Juniper') and John Lawrence Reynolds, who could as well have set their novels in Toronto as in the Boston that they chose.

5 When writers need to be "excused" for where they choose to set their books, or only acceptably Canadian content solves the "problem" of how to include immigrant writers in a discussion of Canadian writing, we have moved into an uncomfortably prescriptive and parochial form of nationalism.

6 And as most of the essays in Detecting Canada show, whether or not a book (or TV show or film) qualifies in some specific way as Canadian turns out to be one of the least interesting questions to ask about it in this context, compared to exploring what kind of crime story it tells and in what way. Sometimes, issues related to Canada or Canadian identity turn out to be central to that story; sometimes they don't. By far the most engrossing essays in the collection, though, are those that let us stop worrying about whether they or their subjects belong, and instead offer detailed analysis of crime fiction that, they convincingly show, rewards our sustained attention.

7 The essay opens with two essays that establish general frameworks for understanding Canadian crime fiction. Beryl Langer's "Coca-Colonials Write Back: Localizing the Global in Canadian Crime Fiction" theorizes Canadian crime fiction as a form of resistance to the overwhelming influence of American popular culture, a "counterhegemonic strategy within the global cultural market." David Skene-Melvin's literaryhistorical essay "Canadian Crime Writing in English" provides a valuable overview of work in this genre as far back as the 1880s (more than proving his point that Howard Engel is not really "the grandfather of Canadian crime fiction"). Skene-Melvin also offers useful grounds for distinguishing Canadian crime writing from other national traditions, especially American : in contrast to the American admiration for outlaws, rebels, and vigilantes, he argues, "the assertion of national authority is the compulsive driving force within the Canadian psyche and is fundamental to crime writing in this country."

Inevitably, it's in these essays with a mandate to generalize that we see the most concern about establishing, and sometimes policing, the boundaries of the "truly Canadian," a phrase Skene-Melvin uses repeatedly. This anxiety falls away in most of the subsequent essays, though it resurfaces occasionally in moments of distracting selfconsciousness. Jeanette Sloniowski's essay "Generic Play and Gender Trouble in Peter Robinson's In a Dry Season," for instance, one of the best in the volume, includes this awkward (and, in my view, wholly unnecessary) apologia :

One of the key questions about Robinson, for the purposes of this book, is how Canadian is his work, given that he mostly sets his novels in Britain and in what could be considered the British tradition .... An important question to ask of Robinson's novels might be why a novel like In a Dry Season, although set in Britain, often seems so Canadian? Or does it seem so Canadian only to particular readers or readers of a certain age? Robinson claims that writing his novels about Britain while living in Canada has given him a clearer perspective on his original homeland ... . I would also argue that In a Dry Season, although set in Britain, has much of interest to many Canadians because the subject is largely about day-to-day life while living in Britain during World War II, as many young Canadian soldiers, both 
male and female, did. .. . The novel must seem familiar to many Canadians whose parents were in Britain in those times and I think that many readers of this popular novel relive the lives of parents and grandparents by learning from Robinson about what life was like for them.

What odd assumptions about Canadian readers - but, even more, what unfortunate inhibitions for Canadian criticism - are hinted at here. Once past this hiccup, Sloniowski's essay goes on to give a rich commentary on the themes and formal innovations of Robinson's novel, in which

use of the village mystery layered over and deftly blended with a police procedural, in the form of a literary palimpsest, is well on its way to a further manipulation of the conventions of both the cozy and the procedural, along with an interrogation of romantic, action-oriented masculinity.

Other essays of note include Brian Johnson's somewhat jargon-laden discussion of Michael Slade's "Gothic RCMP procedurals" which, Johnson argues, "articulate a new northern myth of multicultural nationhood," one that

ritualistically exorcises the ghosts of settler-invader 'post-colonial' nationalism and exploits the ideological structure of the police procedural to managerially assert 'a restored and validated social order.'

11 Manina Jones focuses on Giles Blunt's The Delicate Storm, in which the most "pressing threat" turns out to be "the risk of the Americanization of Canadian space." Jennifer Andrews and Priscilla L. Walton examine Thomas King's Thumps Dreadfulwater novels, in which King

combines the complex political dimensions of Native identity with his own revised notion of the hard-boiled detective, creating a series that writes back not only to Britain, and America, but also Canadian attitudes of imperial righteousness.

12 Pamela Bedore places Gail Bowen's Joanne Kilbourne mysteries in the tradition of feminist detection exemplified by Carolyn Heilbrun : "The series thus is able to speak to current issues within feminist theory as well as to questions regarding the potential of detective fiction to move beyond what has generally been considered its conservative ethos." Looking at how "lesbians and gays are represented" in Anthony Bidulka's Russell Quant mysteries, Péter Balogh critiques Bidulka's series for its "construction of a normative, homogeneous, and depoliticized Canadian gay community" : he concludes that

the Russell Quant mystery series can be read as a cultural site that reflects the management and regulation of contested forms of gender and sexuality and at the same time supports the continued privilege of the whtie masculine middle-class male as the social and cultural ideal.

13 Like the essays on Canadian television shows that conclude Detecting Canada, Bidulka does a particularly good job showing the importance of attending to specifically Canadian social and cultural histories for a full understanding of his particular objects of study: there's no sense that Canadian contexts, or Canadian content, are either peripheral or perfunctory elements of these discussions, as they sometimes seem elsewhere in the book.

14 To their credit, for all that they get occasionally jumpy about who or what is Canadian, most of the essays in Detecting Canada avoid the question too often asked about all genre fiction: "but is it any good?" Only Marilyn Rose's essay on Margaret Atwood's Alias Grace betrays some of the lingering snobbery with which genre fiction is still too often approached. Rose relies on a reductive idea of what crime fiction is usually like in order 
to celebrate Atwood's subversion of its norms. "Detective fiction is an inherently conservative genre," she asserts, and

as such it consoles. There is reassurance in closure, in the way everything 'fits in' and 'comes out' in the end ... and in the idea that rationality can 'solve all' through the application of reason.

But even looking as far back as Edgar Allan Poe and Wilkie Collins it's hard to argue that the outcomes of detective stories are so patly reassuring - in Collins's The Moonstone, for example, the fate of the eponymous diamond may be known at the end of the novel, but it's clear that the wider problems of racism, religious hypocrisy, and xenophobia the case has exposed are far from resolved, while the novel's form challenges complacent assumptions about evidence, testimony, and knowledge itself. Sherlock Holmes may embody all-powerful rationality, but he himself is far from soothing, and Golden Age mysteries such as Agatha Christie's The Murder of Roger Ackroyd rely on the premise that under the right circumstances anyone (even, say, the kindly local doctor) is capable of murder - which is hardly consoling. Hard-boiled novelists like Dashiell Hammett and Raymond Chandler further challenged the terms on which crime was both understood and written about, and contemporary crime novelists frequently address systemic injustices that greatly exceed the capacity of their detectives to make everything 'come out' in the end.

Given the endlessly self-aware and self-referential nature of detective fiction throughout its history (is there any genre more prone to intertextual in-jokes ?), Rose doesn't really need her oppositional set-up between crime fiction and "literary" novelists who turn to it "for purposes of interrogation and subversion" to make her otherwise compelling case that Alias Grace is a novel that

raises profound philosophical questions about the nature of knowledge and particularly the power of positivistic inquiry to solve politically saturated contemporary issues.

In doing so, it seems to me that Alias Grace joins, rather than contrasts with, a great many books that are unapologetic examples of detective fiction. What Detecting Canada does best is show us how many of these examples, often overlooked, lie within the boundaries of Canadian literature. If in doing so it ends up pushing, ignoring, redefining, or just puzzling over those boundaries, well, wondering what it means to be Canadian is perhaps the most Canadian trope of all.

\section{AUTHORS}

\section{ROHAN MAITZEN}

Dalhousie University 